\title{
Gällande gällande och andra avseendemarkörer
}

\author{
Av ULLA STROH-WOLLIN
}

\begin{abstract}
Stroh-Wollin, Ulla, ulla.stroh-wollin@nordiska.uu.se, Professor. Department of Scandinavian Languages, Uppsala University: "Concerning gällande and other "in-what-respect markers" ". Språk och stil NF 29, 2019, pp. 134-167.

This article deals with the development of the kind of lexical items in Swedish that correspond to English regarding, concerning, as regards, with reference to, etc., i.e. lexical items that head phrases specifying in what respect a certain constituent of the clause (or the entire proposition) pertains. A quantitative analysis, based on large newspaper corpora, reveals a most dynamic situation: "in-what-respect markers" come and go. Two newcomers have appeared recently, gällande (from the participle of gälla 'concern') and när det kommer till (borrowed, word for word, from English when it comes to), while others, e.g. beträffande ('concerning') and i fråga om (lit.: in question about) are rapidly losing ground. However, the decline of the latter started before the former were beginning to gain ground. Instead, it seems as när det gäller (lit. when it concerns), the - beyond comparison - most frequent in-what-respect marker in present-day Swedish, and the related vad gäller (lit. [in] what concerns) have ousted - from a very modest position before 1950 - earlier more frequent variants. The hypothesis that a competitive in-what-respect marker should be syntactically versatile is tested and strengthened, but it does not fully explain the complex dynamics of the field. Nevertheless, the author dares to predict some further success of both gällande and när det kommer till.
\end{abstract}

Keywords: participial prepositions, complex prepositions, Swedish, angående, beträffande, gällande, rörande, vad gäller, när det gäller, när det kommer till.

\section{Inledning}

Den undersökning som presenteras i det följande startade för några år sedan med iakttagelsen att ordet gällande, tycktes det mig, hade fått fotfäste som preposition och användes ungefär på samma sätt som beträffande eller angående. Ett autentiskt exempel återges i (1). ${ }^{1}$ Kursiven i exemplet avser den fras som utgörs av gällande + dess komplement. Samma princip används genomgående i artikeln.

${ }^{1}$ Ett exempel från min handledarvardag som återges med författarens tillstånd. 
(1) Även gällande $O V$-ordföljd finns det en stor variation mellan texterna.

När jag först lade märke till detta prepositionella bruk av gällande kändes det främmande. Själv hade jag i en mening som den i (1) i stället valt till exempel beträffande eller ett flerordsuttryck som när det gäller eller vad gäller, möjligen $i$ fråga om.

En kontroll i några ordböcker gav mig stöd, såtillvida att de inte presenterade gällande som en preposition. Fortfarande i 14:e upplagan av Svenska Akademiens ordlista (SAOL) från 2015, liksom i Svensk ordbok från 2009, är ordet enbart ett oböjligt adjektiv. Som adjektiv används det bland annat i uttryck som göra gällande, göra sig gällande och gällande lag. I Svenska Akademiens grammatik (från 1999), hädanefter SAG, exemplifieras prepositioner som bildats genom »lexikalisering» av presensparticip med beträffande, rörande och angående (SAG del 2 s. 716). Gällande som preposition nämns inte i detta sammanhang eller annorstädes i verket. Såväl beträffande som rörande och angående noteras som prepositioner även i SAOL och Svensk ordbok. Däremot tar inget av de nämnda verken upp avseende som preposition, fastän ordet används (ehuru ganska sällan) i denna funktion.

Efter en inledande sondering i Språkbankens korpusar stod det klart att gällande verkligen var en preposition på frammarsch. Det framkom också att beträffande och vad beträffar är på snabb reträtt. Det framstod alltså som om det sker en sorts ommöblering bland den här sortens uttryck, som jag i det följande kommer att omtala som avseendemarkörer och se som konkurrenter inom funktionsdomänen (eller fältet) »markera avseende» (se vidare nedan). En intressant omständighet är att denna ommöblering tycks ske ganska obemärkt, trots att förändringarna är klart mätbara på bara några decennier.

Det övergripande syftet med föreliggande studie har varit att försöka förstå hur de olika avseendemarkörerna förhåller sig till varandra och hur fältet »markera avseende» förändrats under modern tid. Den empiriska undersökningen bygger på excerpering av olika presskorpusar som är tillgängliga i Språkbanken. Dessa har använts för att kartlägga de olika avseendemarkörernas frekvens, inbördes fördelning och vissa grammatiska egenskaper vid olika tidpunkter. Mina exempel i det följande är hämtade ur detta material när inget annat anges. Jag markerar i dessa fall efter varje exempel från vilken specifik korpus det är taget. 


\subsection{Termen avseendemarkör}

De ord och uttryck som behandlas nedan har det gemensamt att de inleder fraser som på något vis inskränker ett satsleds eller hela propositionens giltighet $\mathrm{i}$ ett visst avseende. Trots att de kan skifta i form är de ofta utbytbara mot varandra. Som framgått ovan vore såväl beträffande som vad gäller och i fråga om möjliga alternativ till gällande i exemplet i (1). Termen avseendemarkör är ett sätt att fånga dem alla i ett enda begrepp utifrån den gemensamma funktionen att markera avseende.

I SAG (del 3 s. 552) identifieras en särskild typ av adverbial som uttrycker just avseende. (Se också Holm 1991.) Dessa »avseendeadverbial» är, enligt beskrivningen, ofta uppbyggda kring ett semantiskt tungt adjektiv (t.ex. formellt eller spelmässigt sett), men, avslutar man, »[h]it hör också adverbial inledda med prepositioner med betydelse av 'avseende' som ifråga om, vad gäller, beträffande». Typen illustreras i SAG med exemplen i (2a-c).

(2) a. Också Engqvist har fel i fråga om pappret.

b. I Stockholm har vi kommit jämförelsevis långt vad gäller utbyggnaden av barnomsorgen.

c. Jakob instämde med mig beträffande mötesförberedelserna.

Något som inte framgår i SAG är att fraser som inleds med i fråga om, vad gäller, beträffande etc. inte nödvändigtvis fungerar som adverbial. De kan även vara attribut i nominalfraser, se exemplen i $(3 \mathrm{a}-\mathrm{c})$.

(3) a. Den största stegringen $i$ fråga om tonnage avser de egentliga motorfartygen ... (ORDAT)

b. Debatten om kvoter vad gäller inhemsk produktion och köp utifrån pågår ständigt. (GP 1994)

c. Kraven på lagändringar beträffande innehav av illegala vapen är välbefogade ... (GP 2013)

I SAG beskrivs avseendemarkörerna genomgående som prepositioner; i fråga om och vad gäller ses som komplexa prepositioner (SAG del 2 s. 719). Jag har dock tvekat inför den beteckningen för de uttryck som innehåller finita verb, bland annat för att ett par av dem tillåter tempusväxling; exempelvis förekommer när det gällde vid sidan av det vanligare när det gäller. För enkelhetens skull har jag därför valt den gemensamma beteckningen avseende-markör.

För säkerhets skull bör det också påpekas att även vanliga enkla prepositioner, kanske särskilt om, ibland kan ersätta ovan nämnda uttryck. Begreppet avseendemarkör omfattar dock endast sådana uttryck vars primära uppgift är att markera just avseende. 


\subsection{Svenskans avseendemarkörer}

Arbetsnamnet på min undersökning har hela tiden varit »Gällande gällande»» kort och gott, eftersom det var nykomlingen gällande som först väckte mitt intresse. Relativt snart stod det emellertid klart att det var lämpligt att försöka inventera förrådet av avseendemarkörer för att få en överblick över hela avseende-fältet. Ambitionen har varit att hitta alla avseendemarkörer som används i modern svenska. ${ }^{2}$ Till dessa hör ytterligare en nykomling vid sidan om gällande, nämligen när det kommer till. Till en början uppfattade jag när det kommer till som en rent tillfällig anglicism, men också detta uttryck har helt klart fătt fotfäste i svenskan.

Formmässigt kan avseendemarkörerna indelas i tre huvudsakliga typer: sådana som har sitt ursprung i presensparticip, sådana som har sitt ursprung i finita bisatsmatriser, en del inledda med $v a d$, andra med när, samt komplexa prepositioner uppbyggda enligt mönstret preposition + substantiv + preposition. Jag räknar med följande varianter av de olika typerna:

- participformade prep.:

angående
avseende
beträffande
gällande
rörande

- finita matriser: vad $(\mathrm{x})$ angår/vad angår $(\mathrm{x})$
vad avser
vad $(\mathrm{x})$ beträffar/vad (det) beträffar $(\mathrm{x})$
vad $($ det $)$ gäller/gällde
när/då det gäller/gällde
när det kommer till

- prep. + subst. + prep.:

i fråga om med avseende $p a ̊$

I den andra gruppen ovan, där uttrycken uppvisar viss formmässig variation, får fortsättningsvis följande beteckningar representera alla varianter av respektive uttryck: vad (...) angår, vad (...) beträffar, vad (det) gäller, när det gäller.

Att verben angå, avse, beträffa och gälla återkommer i mer än en avseendemarkör hänger rimligtvis samman med att de gärna används med en uttunnad

\footnotetext{
${ }^{2}$ Jag har däremot inte beaktat äldre varianter som anbelangande(s) eller vidkommande, som knappast är i bruk idag, och inte heller vad (...) anbelangar, som möjligen förekommer, men är tämligen ovanligt.
} 
avseendebetydelse, även om de i andra sammanhang kan ha en mer pregnant innebörd, som t.ex. då avse står för 'ha för avsikt' eller gälla för 'vara giltig'. Det är väl också sannolikt att en konstruktion banat vägen för en annan med samma verb.

\subsection{Forskningsbakgrund}

Just avseendemarkörer som kategori har inte tilldragit sig särskilt stor uppmärksamhet i forskningen. (Däremot har lexikografer förstås haft anledning att beakta enskilda uttryck, se vidare avsnitt 1.5.) Att det finns vissa adverbial som kan betecknas som avseendeadverbial uppmärksammades, såvitt jag kunnat utröna, för första gången av Lisa Holm (1991) i en uppsats som senare kom att ligga till grund för den paragraf i SAG (del 3, adverbial, § 115) där typen behandlas. Holms uppsats handlar emellertid inte om fraser som inleds med de uttryck som behandlas här, utan om fraser som formellt sett, spelmässigt etc. I SAG:s behandling (ibid.) nämns, som framgått, även fraser med beträffande, vad gäller, i fråga om etc. men inte att sådana fraser också kan fungera attributivt (jfr avsn. 1.1).

Det finns emellertid en relativt färsk artikel som verkligen behandlar några svenska avseendemarkörer, Anton Granvik \& Susanna Taimitarha (2014): »Topic marking prepositions in Swedish: A corpus-based analysis of adpositional synonymy», som tar upp angående, gällande, beträffande och rörande, dvs. fyra av de fem participformade uttrycken jag identifierat ovan, men inte avseende. Som framgår av uppsatsens titel betecknar författarna dessa ord som topikmarkörer, vilket skulle kunna tolkas som en snävare funktionell avgränsning än den jag gör med termen avseendemarkör, men så är inte fallet. Som jag återkommer till nedan används avseendemarkörer bara ibland, och inte primärt, som inledare av fraser som uttrycker topik i en mer etablerad bemärkelse, men Granvik \& Taimitarhas term inskränker sig alltså inte endast till detta bruk, utan avser ordens användning i stort. ${ }^{3}$

Granvik \& Taimitarhas artikel handlar om hur man ska kunna identifiera semantiska, grammatiska och kontextuella skillnader mellan de fyra prepositionerna för att definiera dem i relation till varandra. Utgångshypotesen var att to-

\footnotetext{
${ }^{3}$ König \& Kortmann (1991 s. 120) identifierar tre huvudsakliga domäner för engelska verbavledda prepositioner, varav en är »topic/perspective». Här finner man bland annat prepositioner som concerning och regarding, dvs. motsvarigheter till svenskans beträffande, angående etc. Beskrivningen »perspective» ligger, som jag ser det, närmare betydelsen 'avseende' än 'topik', men jag menar att det svenska begreppet faktiskt bäst fångar vad det är fråga om.
} 
tal synonymi inte existerar: »one form - one meaning». Undersökningen är baserad på excerpering av samtliga förekomster av de respektive prepositionerna i PAROLE-korpusen, vilka sedan blir föremål för en sofistikerad statistisk analys. PAROLE-korpusen inbegriper blandade genrer - romaner, tidningar, tidskrifter och webb-texter - från 1990-talet. Den omfattar drygt 24 miljoner tokens och finns tillgänglig för sökning på Språkbanken.

De genomförda analyserna visade att beträffande var den klart mest frekventa av de fyra prepositionerna (466 belägg) och den som framstod som förstahandsalternativet i många fall. Den föredras vid självständigt adverbiellt bruk, typiskt i initial position. Den näst vanligaste prepositionen var rörande (199 belägg); den används nästan uteslutande attributivt och framstår mest som ett stilistiskt alternativ tillsammans med någon av de övriga. Nästan lika vanlig som rörande är angående (187 belägg) som särskilt används som komplement vid ord för kommunikation. Den minst frekventa prepositionen är gällande (77 belägg) som, liksom rörande, används företrädesvis attributivt.

Trots att man således kan identifiera vissa skillnader mellan de fyra studerade prepositionerna är Granvik \& Taimitarhas slutsats att dessa skillnader är subtila och att deras analys snarast understryker hur lika orden är. Detta var inte författarnas förväntade (eller önskade) resultat. Som läsare kan man emellertid tycka att det »negativa» resultatet är väl så intressant. Uppenbarligen råder en stor semantisk och funktionell överlappning mellan de olika participformade avseendemarkörerna.

\subsection{Teoretiska utgångspunkter och preciserade frågeställningar}

Den undersökning jag redogör för i det följande utgår delvis ifrån samma frågor som Granvik \& Taimitarha (2014) ställde sig, men den skiljer sig från deras studie på ett par viktiga punkter. Dels anlägger jag ett diakront perspektiv, dels ser jag på hela funktionsdomänen »markera avseende» och beaktar alla de olika typerna av avseendemarkörer, dvs. inte enbart de participformade.

Inom semantiken talar man ibland om samlingar av betydelsebesläktade ord som semantiska fält eller semantiska domäner. När jag talar om funktionsdomänen, eller fältet, »markera avseende» använder jag samma sorts rumsliga metaforik om den samling av ord och uttryck med funktionen att markera avseende som är undersökningsobjektet i denna studie.

Just en funktionsdomän som »markera avseende» låter sig relativt lätt avgränsas; antalet ord och uttryck som kan räknas in är måttligt, vilket är natur- 
ligt med tanke på att den funktion de fyller inte är särskilt komplex. Intressant nog är de ändå fler än några enstaka. Dessutom visar det sig att avseendemarkörer, kanske i högre grad än man spontant föreställer sig, kommer och går. Denna dynamik motiverar i hög grad ett diakront studium. Och det faktum att det råder en påfallande stor utbytbarhet mellan uttrycken inom domänen, också mellan sådana av olika strukturell typ, motiverar att man tar dem alla i beaktande.

Trots att den semantiska och funktionella överlappningen mellan de olika avseendemarkörerna är avsevärd, tror jag att det ligger något i devisen »one form - one meaning» som är värd att ta till vara, även i detta sammanhang. Om språket, som devisen implicerar, gör motstånd mot en hög grad av synonymi, så ligger det också i sakens natur att likvärdiga ord och uttryck konkurrerar med varandra och att vissa försvinner.

Min utgångpunkt i det följande är att fältet »markera avseende» kan, mutatis mutandis, jämföras med ett biologiskt ekosystem. I ekosystemet kan inte alltför lika arter samexistera; var och en måste ha sin egen (som ekologerna kallar det) nisch. Konkurrens mellan arter som är väldigt lika leder till att en av dem tar över helt eller till att flera blir kvar genom att specialisera sig inom olika, men smalare nischer. ${ }^{4} \mathrm{Nu}$ behöver man inte dra parallellen så långt att vi ska förvänta oss att bara en enda av avseendemarkörerna skulle kunna överleva. Men om man utgår ifrån att behovet av avseendemarkörer i princip borde vara mättat i ett språksamhälle med en väl utvecklad skriftspråkskultur och ett antal etablerade texttyper av resonerande karaktär, så är det inte orimligt att tänka sig att en markör som av någon anledning växer sig allt starkare gör det på andras bekostnad.

En hypotes som undersöks i det följande är att förmåga att uppträda i olika syntaktiska kontexter är en konkurrensfördel, så att en avseendemarkör som har eller utvecklar en större funktionell bredd än andra brer ut sig mer än vad som står i direkt proportion till antalet användningsområden. För avseendemarkörernas del tänker jag att det finns två grammatiska egenskaper som därvid är basala. Den ena är förmågan att ta komplement av olika form. Ett komplement till en avseendemarkör är alltid ett nominalt led. Oftast är komplementet en vanlig nominalfras med ett substantiviskt huvudord, men också nominala bisatser, dvs. att-satser och interrogativa bisatser, samt infinitivfraser förekommer. Den andra basala egenskapen handlar om i vilka syntaktiska positioner som av-

\footnotetext{
${ }^{4}$ Termen nisch etablerades under det tidiga 1900-talet, men ansluter förstås till darwinistiska föreställningar om konkurrensen mellan arter. Se vidare Pocheville 2015 för en genomgång av nisch-begreppet och dess utveckling.
} 
seendefrasen, dvs. avseendemarkören + komplementet, kan förekomma. Används dessa fraser t.ex. lika gärna i attributiv som i adverbiell funktion?

Uppenbarligen uppstår nya avseendemarkörer ibland, vilket rimligen bidrar till dynamiken inom fältet. Hur kommer detta sig? I sin uppsats »On the reanalysis of verbs as prepositions», som bland annat handlar om prepositioner som concerning och regarding, skriver König \& Kortman (1991 s. 121) att »deverbal prepositions tend to develop where primary prepositions are not available». Avseendemarkörer fyller alltså en funktion där »vanliga» prepositioner inte räcker till. Men detta förklarar inte att nya avseendemarkörer uppstår i ett läge där man kan tycka att språket redan förfogar över ett tillräckligt antal olika varianter.

Jag utgår i detta sammanhang ifrån att avseendemarkörer inte bara uppkommer för att de behövs; de är även resultat av spontana språkliga processer, inte sällan grammatikaliseringsprocesser. Som grammatikaliserade avseendemarkörer tänker jag mig främst dem som utvecklats ur verbala uttryck. De skulle då vara exempel på det första steget i den utveckling som återges i (4), hämtad ur Hopper \& Traugott 2003 (s. 7), och som illustrerar hur ett »icke-grammatiskt» uttryck kan övergå i ett formord och senare i ett bundet grammatiskt morfem. Exempelvis kan avseendemarkören gällande förstås som en omtolkning av ett verbalt presensparticip (ett innehållsord) som preposition (ett formord).

(4) content item $>$ grammatical word $>$ clitic $>$ inflectional affix

Det finns mycket inom grammatikaliseringsforskningen som är omdebatterat, t.ex. huruvida det finns anledning att tala om en grammatikaliseringsteori eller om grammatikalisering »bara» är ett fenomen med vissa typiska drag. Olika forskare har också helt olika syn på vad det är som driver grammatikaliseringsprocesser, t.ex. vilken roll man ska tilldela semantisk blekning respektive syntaktisk förenkling (se t.ex. Rosenkvist 2006 för en diskussion).

Här använder jag termen grammatikalisering enbart som beteckning på en process - en process där ett innehållsord, eller ett flerordsuttryck, genomgår en grammatisk omtolkning och antar karaktär av formord. En sådan omtolkning blir tydlig då ordet/uttrycket uppvisar förändrade grammatiska egenskaper. Detta konkretiseras kort nedan, med gällande som exempel, för att underlätta den fortsatta läsningen. I övrigt finner jag ingen anledning att inta den ena eller andra teoretiska positionen i detta sammanhang, eftersom min empiriska undersökning inte avser hur enskilda avseendemarkörer uppkommer (även om jag något återkommer till den aspekten i diskussionen i avsnitt 4).

Det är, som nämndes ovan, i första hand de olika verbala uttryckens utveck- 


\section{Ulla Stroh-Wollin}

ling till avseendemarkörer som jag betraktar som grammatikaliseringsprocesser. Jag utgår i dessa fall ifrån att de olika verbens mera pregnanta betydelser, som t.ex. 'giltig' för gällande, inte har aktualiserats i de kontexter där en grammatisk omtolkning skett, vilket inte utesluter att subtila betydelseskillnader mellan uttrycken kan kvarstå. Vidare utgår jag ifrån att de participformade prepositionerna har startat som verbala particip i efterställda attributiva fraser (jämförbara med relativsatser), medan fraser som inleds med uttryck som när det gäller och när det kommer till kan antas ha haft uteslutande adverbiell funktion i början. Men med fortgående grammatikalisering börjar båda typerna av fraser alltmer anta karaktär av prepositionsfraser, vilket borde möjliggöra såväl adverbiell som attributiv användning. Därmed kan man förvänta sig att participfraserna också dyker upp som adverbial och de när-inledda finita uttrycken också som attribut.

En kontroll bland gällande-fraserna i det undersökta pressmaterialet stöder antagandet om utvecklingsgången. I de äldsta korpusarna inleder gällande alltid attributiva fraser, som i (5a), men senare under 1900-talet förekommer de även i adverbiella fraser, alldeles entydigt så i t.ex. (5b).

(5) a. Slutligen överlämnades även den mindre medaljen [...] för ett banbrytande tekniskt forskningsarbete gällande utvecklingen av indirekt kokning vid tillverkning av sulfat- och sulfitcellulosa. (ORDAT: 1933)

b. Däremot är han upprörd över att vi tycker att Olof Johansson agerade senfärdigt gällande Skagerrak när han ännu var miljöminister. (GP 1994)

En adverbiell fras kan förstås även uppträda i fundamentsposition. I de flesta fall är detta endast ett alternativ till en senare placering, så t.ex. i (6a), där en final placering av gällande läget $i$ truppen skulle vara lika grammatisk. Men ibland får avseendefrasen en mer självständig karaktär av topiksättare och kan inte lika lätt flyttas; detta gäller t.ex. (6b). Ibland kan den även stå som ett fritt topikled före en sats eller en replik, som (6c).

(6) a. Gällande läget $i$ truppen är han dock positiv. (GP 2013)

b. Gällande själva fartygsolyckan anser hon att Estonia ska bärgas. (GP 1994)

c. Slutligen gällande frånvaron av innehållsdeklaration ställd av museet: Crispin, visst är det skönt att slippa den här typen av trygghetsförsäkringar ... (GP 1994)

Alla avseendemarkörer förekommer till någon del i både $\mathrm{i}$ attributiva och adverbiella fraser. Däremot är det inte självklart att de gör det i samma utsträckning. Enligt min hypotes bör en framgångsrik avseendemarkör visa stor varia- 
tion härvidlag. Om den dessutom gärna inleder topikfraser, satsintegrerade och kanske till och med fristående sådana, så är det ytterligare tecken på dess breda användbarhet.

Sammanfattningsvis ser jag alltså funktionsdomänen »markera avseende» som ett fält där det råder konkurrens om utrymmet. Systemet är inte statiskt, bland annat eftersom det inte är slutet, utan öppet och släpper in nya avseendemarkörer efter hand. Undersökningen går ut dels på att beskriva själva dynamiken inom denna domän, dels på att testa hypotesen att syntaktisk allsidighet är en konkurrensfördel. Därmed kan följande konkreta frågor formuleras för undersökningen:

- Hur vanliga är olika avseendemarkörer vid olika tidpunkter? Hur förändras deras inbördes styrkeförhållanden över tiden?

- Vilka komplement tar de olika avseendemarkörerna och kan man se någon utveckling i detta avseende?

- I vilka syntaktiska positioner uppträder fraser som inleds med de olika avseendemarkörerna och kan man se någon utveckling i detta avseende?

Undersökningen berör inte eventuella semantiska skillnader mellan olika uttryck, även om sådana skulle kunna spela en viss roll för utvecklingen, egentligen både för de framgångsrika uttryckens förmåga att breda ut sig på andras bekostnad och för kvantitativt marginella att behålla en plats i systemet. Upplägget ger emellertid inte utrymme för analyser av detta slag.

\subsection{Avseendemarkörerna i Svenska Akademiens ordbok}

Innan vi går vidare finns det anledning att också kort summera vad som framkommer om de olika avseendemarkörerna i Svenska Akademiens Ordbok (SAOB), eftersom detta kan bidra till det diakrona perspektivet.

Artiklarna angå, angående, afse, afseende (samtliga från 1898), beträffa, beträffande (båda från 1908), gälla (1929), rörande (1962) samt fråga (1926) visar att en del av avseendemarkörerna är välbelagda tidigt, medan andra inte nämns. Den utslätade betydelsen hos angå, avse, beträffa, gälla och röra, ${ }^{5}$ som går igen i dessa verb och i de relaterade participen i avseendemarkörerna, föreligger emellertid i samtliga fall senast på 1700-talet.

Av de participformade uttrycken beskrivs angående, beträffande och rörande som sedan länge etablerade prepositioner. Också uttrycken vad (...) angår och vad (...) beträffar är tidiga. Liksom verben angå och beträffa i sig har

\footnotetext{
${ }^{5}$ Dessa verb återkommer själva i varandras betydelsebeskrivningar.
} 
den prepositionella användningen av participen och uttrycken vad (...) angår och vad (...) beträffar tyska förebilder (och föreligger även i danskan och holländskan $\left.{ }^{6}\right)$.

Till skillnad från de just nämnda uttrycken presenteras varken gällande, när det gäller eller vad (det) gäller som avseendemarkörer i SAOB - trots att verbet gälla i sig redan på 1500-talet uppvisar en allmän betydelse av 'vara fråga om, röra sig om, avse'. Att gällande saknas förvånar förstås inte, men däremot möjligen att varken när det gäller eller vad (det) gäller tas upp.

Liksom i de moderna ordböckerna beskrivs inte participet avseende som preposition i SAOB. Inte heller nämner man förbindelsen vad avser. Däremot framgår att verbalsubstantivet avseende i förbindelsen med (alt. $i$ ) avseende på använts åtminstone sedan 1700-talet. Det senare gäller även förbindelsen $i$ fråga om.

Av artiklarna om angående och beträffande framgår explicit att fraser som inleds med dessa ord kan fungera både attributivt (»efter subst.») och adverbiellt (»vid verb 1. adj.»), men även utgöra »en fristående förbindelse utan syntaktisk anslutning till ngt ord 1. uttryck i satsen» (identiskt formulerat i båda artiklarna). Det senare innebär i regel att uttrycket står vänsterdislokerat, dvs. före fundamentet i den följande satsen. Det framgår genom en hänvisning i artikeln beträffande till artikeln beträffa att denna möjlighet föreligger även för hvad beträffar.

I övriga fall är den syntaktiska beskrivningen inte lika explicit. Av de givna exemplen framgår dock att fraser med andra etablerade avseendemarkörer än de ovan nämnda som inledare kan uppträda med både attributiv och adverbiell funktion. Däremot ges i dessa artiklar inga ytterligare exempel på vänsterdislokerade topikfraser. Detta kan bero på att sådana saknas, men det behöver ju inte nödvändigtvis vara så.

\section{Material och metod}

Som framgått ovan bygger föreliggande studie på belägg som hämtats från Språkbankens pressmaterial. I avsnitt 2.1 diskuterar jag valet av korpusar, i avsnitt 2.2 redogör jag för excerperingsförfarandet och i avsnitt 2.3 för beräkningarna. Undersökningens akribi kommenteras kort i avsnitt 2.4.

${ }^{6}$ SAOB:s benämning; väl sannolikt liktydigt med nederländskan. 


\subsection{Korpusval}

Materialet till studien har primärt hämtats från 22 olika korpusar med blandat pressmaterial från början av 1900-talet och fram till 2013. Från de senaste decennierna har det varit möjligt att gruppera materialet $i$ tre femårsperioder (1994-98, 2001-05, 2006-10) och en treårsperiod (2011-13), vilket ger sammantagna korpusar om 54-103 miljoner tokens för dessa perioder. Tidigare decennier är mera glest representerade. Dessa korpusar är också mycket mindre, från drygt en miljon tokens (Press 65) till drygt fem miljoner tokens (DN 1978). Detta har vissa konsekvenser för analysen, som jag återkommer till. Materialläget kan sammanfattas enligt följande:

- ORDAT: SvD:s årsbok 1923-45, 1948, 1958

- Press 65

- Press 76

- DN 1987

- GP 1994 + Press 95-98

- GP 2001-2005

- GP 2006-2010

- GP 2011-2013
1,53 miljoner tokens

1,12 miljoner tokens

1,35 miljoner tokens

5,12 miljoner tokens

60 miljoner tokens

103 miljoner tokens

93 miljoner tokens

54 miljoner tokens

Utöver detta material har jag för en kompletterande undersökning gjort sökningar i Aftonbladet från 1830-tal till 1860-tal, som finns tillgängliga i samlingen Kubhist bland Språkbankens historiska material (se vidare om detta i avsnitt 3).

Valet av pressmaterial faller sig naturligt av olika skäl. Tidningsprosa kan förväntas innehålla ett för resonerande skriftspråk representativt urval av olika avseendemarkörer. De texter som förekommer i dagstidningar är naturligtvis resonerande i olika hög grad, men blandningen av journalistiska genrer kan snarast anses främja just ett representativt urval. Det är också en fördel att det rör sig om texter skrivna av ett större antal författare, vilket innebär att man normalt inte behöver befara att t.ex. specifika skribenters stil får ett omotiverat genomslag. Naturligtvis kan man inte helt bortse ifrån att journalistiska stilideal eller det relativa utrymme som ägnas nyheter, kultur, sport etc. kan förändras över tiden och att det i någon mån kan påverka utfallet.

När det gäller korpusarna från 1965 och framåt är jämförbarheten i nämnda avseenden sannolikt så god man kan begära. Svenska Dagbladets årsbok ger ett mera formellt intryck, men har ändå bedömts som tjänlig för att förlänga perspektivet bakåt till förra halvan av 1900-talet. ${ }^{7}$

\footnotetext{
${ }^{7}$ Det kan också påpekas att jag helt och hållet har utgått ifrån sverigesvenskt textmaterial. Jag har, mot bakgrund av att Granvik \& Taimitarha (2014), som är finländare, utan kommentar inbegrep gällande i sin undersökning, i efterhand gjort kontrollsökningar på gällande i några av Språkbankens korpusar med finlandssvenska dagstidningar. Utan att gå in på detaljer tyder resultatet av dessa sökningar på att gällande som preposition faktiskt etablerades något tidigare i finlandssvenskan än i sverigesvenskan.
} 
En stor fördel med presskorpusarna från de senare decennierna är storleken. De olika avseendemarkörernas relativa frekvens varierar stort, dels sinsemellan, dels i enskilda fall över tiden. Också av denna anledning är det inte överdrivet att räkna frekvenser utifrån en samlad textmängd på 50 till 100 miljoner ord. Frågan är hur man ska förhålla sig till de tidigare, i detta sammanhang, små korpusarna.

Det finns två principiella problem när det gäller korpusarnas storlek. Det ena är förstås att felmarginalen för frekvensuppgifter ökar ju mindre korpusen är och kan vara än mer besvärande om de ord och uttryck man undersöker är lågfrekventa. Det andra problemet är mindre uppmärksammat, nämligen att det kan det vara komplicerat att jämföra relativa ordfrekvenser i material av mycket olika storlek. I takt med att en korpus utökas tillkommer hela tiden nya ord, vilket innebär att den relativa frekvensen, t.ex. räknad som förekomst per tusen eller en miljon ord, förändras för alla belagda ord. Dessutom förändras den på olika sätt för ord som är olika vanliga. Med ökande korpusstorlek planar skillnaden ut. Har man väl kommit upp i en viss korpusstorlek blir alltså utfallet någorlunda tillförlitligt och jämförbart. Men utfallet av en sökning i en korpus som befinner sig en bit under denna storlek kan vara svårt att jämföra med motsvarande sökning i en större korpus. ${ }^{8}$

Hur stor måste då korpusen vara för att frekvensen ska ha uppnått en någorlunda stabil nivå? Detta problem har jag för denna studies vidkommande försökt bestämma på ett förhållandevis praktiskt sätt. Utifrån de frekvenser jag räknat fram för olika avseendemarkörer förefaller det som om korpusen DN 87 med sina drygt fem miljoner tokens ger ett utfall som förfaller logiskt i jämförelse med de senare, mycket större korpusarna. I de mindre korpusarna, som täcker mellan en och en och en halv miljon tokens, uppträder många av avseendemarkörerna däremot med en misstänkt hög frekvens. När det gäller ORDAT-materialet kan detta delvis hänga samman med texternas formella karaktär, men också Press 65 och Press 76 visar höga frekvenser jämfört med de senare korpusarna.

För att ytterligare skaffa mig en uppfattning om korpusstorlekens betydelse för frekvensen har jag undersökt utfallet i korpusar av olika storlekar för fyra ord där man inte förväntar sig större tidsmässiga fluktuationer. Jag valde med

\footnotetext{
${ }^{8}$ Tack till Lars Borin, Språkbanken, som orienterat mig om detta och tipsat mig om Baayen: Word frequency distributions (2001). Denna bok har om inte annat gjort det klart för mig att analys av ordfrekvens är ett mycket komplicerat område. Efter samtal med statistiker har jag förstått att en mera sofistikerad statistisk analys av det material jag behandlar i denna studie skulle kräva betydligt större insats än den eventuella vinsten vore värd. Jag nöjer mig således här med både en förenklad beskrivning och ett förenklat analysförfarande.
} 
hjälp av Nusvensk frekvensordbok (del 1: Allén 1970) ut fyra ord som ligger på lite olika plats inom ett för denna studie relevant frekvensspann, nämligen fanns, helst, sida och stigit. Den relativa frekvensen (belägg per en miljon tokens) beräknades på följande material (i storleksordning): Press 65 (1,12 miljoner tokens), Press 76 (1,35 miljoner tokens), DN 87 (5,12 miljoner tokens), Press 96 (6,52 miljoner tokens), Press 95 (7,68 miljoner tokens), Press 98 (10,7 miljoner tokens), Press 97 (13,7 miljoner tokens), GP 1994 (21,3 miljoner tokens), GP 2011-13 (54 miljoner tokens), GP 2006-10 (93 miljoner tokens) och GP 2001-05 (103 miljoner tokens). Utfallet ses i figur 1.

Av figuren framgår att frekvensen i Press 65 är jämförelsevis mycket hög $\mathrm{i}$ tre av de fyra beräkningarna. I Press 76 är den lika hög för sida och klart förhöjd även för stigit. DN 87 däremot visar genomgående värden som ligger ganska nära dem som gäller i de stora korpusarna. Och även om man kan se fluktuationer i frekvens när det gäller det lägre korpusspannet, menar jag ändå att kontrollen visar att DN 87 går att jämföra med de större korpusarna när det gäller frekvensberäkningar.

Däremot bedömer jag att det finns anledning att inte ta med de tre äldsta korpusarna, dvs. ORDAT, Press 65 och Press 76, vid jämförelser mellan olika avseendemarkörers relativa frekvens. Det äldsta materialet kommer emellertid att

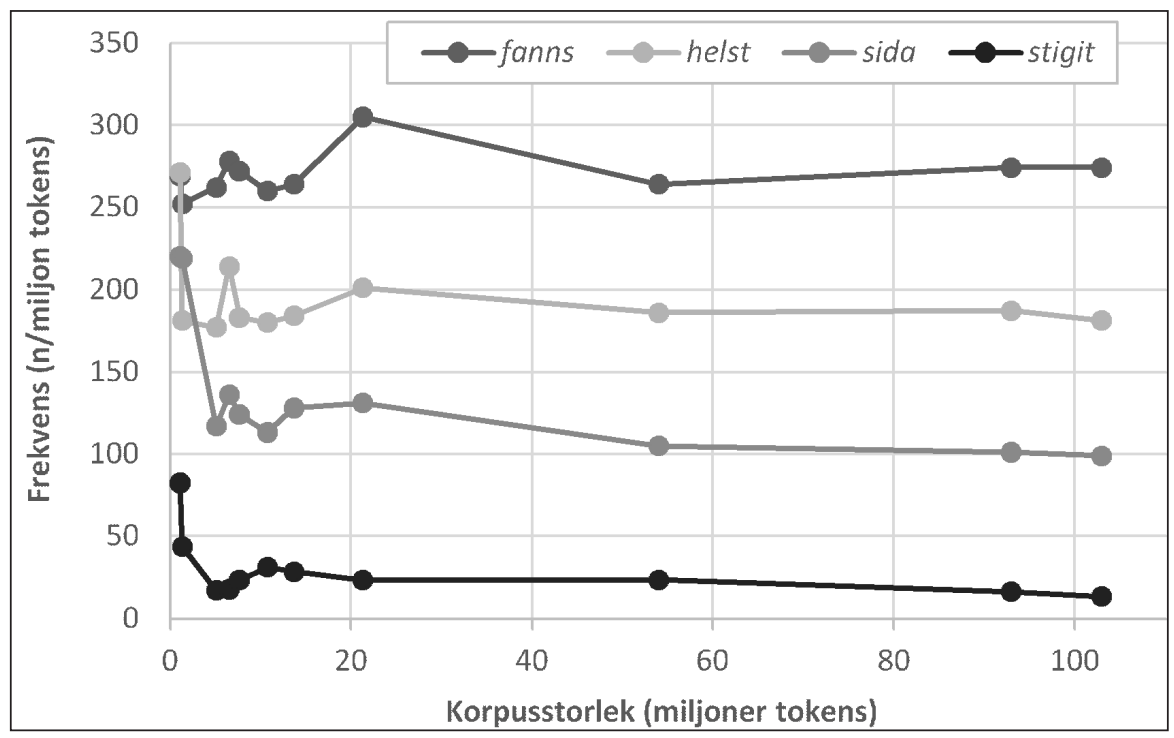

Figur 1. Den relativa frekvensen för orden fanns, helst, sida och stigit i korpusar av olika storlek. 
beaktas vid jämförelser av den procentuella fördelningen mellan olika avseendemarkörer inom de enskilda korpusarna. Också denna fördelning är mindre tillförlitlig i de mindre korpusarna än i de större, men om man vill studera huvudtendenserna fyller de en funktion.

\subsection{Excerpering och sortering av belägg}

Excerperingen av belägg har primärt gjorts med hjälp av sökverktyget Korp. Dessa sökningar har inte i något fall utnyttjat Språkbankens ordklasstaggning, som bedömts som alltför otillförlitlig för mina syften i detta sammanhang. Därmed har naturligtvis ett antal sökningar gett en rad träffar som inte är belägg på de eftersökta avseendemarkörerna, vilka då har måst sorteras ut manuellt i de filer där sökträffarna sparats. I de fall antalet belägg är mycket stort har utsorteringen gjorts med hjälp av sökning på utslagsgivande söksträngar och viss efterkontroll.

Följande gäller för utsorteringen av irrelevanta sökträffar:

- angående

- avseende

- beträffande

- gällande

- rörande

- $\operatorname{vad}(\ldots)$ angår

- vad avser
- Ingen manuell utsortering har gjorts.

- Träffar på avseende som substantiv har sorterats ut manuellt.

- Ingen manuell utsortering har gjorts.

- Träffar på gällande har sorterats ut manuellt när ordet fungerar som pre-nominalt attribut (som i gällande lag) och predikativ ( $x$ är gällande) samt i uttrycken göra gällande (att ...) och göra sig gällande, därutöver som efterställt attribut i betydelsen 'giltig' (ex.: en ny tidtabell, gällande från 15 januari).

- Träffar på rörande som adjektiv i betydelsen 'gripande' $\mathrm{i}$ attributiv, predikativ och adverbiell funktion (ex.: en rörande historia) samt som verbalt eller substantiverat particip med bibehållen konkret grundbetydelse (ex.: två timmars rörande $i$ grytorna) har sorterats ut manuellt.

- Träffar på vad angår har sorterats ut i de fall vad har interrogativ betydelse (ex.: Vad angår det här mig?).

- Träffar på vad avser har sorterats ut i de fall vad har interrogativ betydelse (ex.: Vad avser du att göra härnäst?). 
- $\operatorname{vad}(\ldots)$ beträffar $\quad$ - Ingen manuell utsortering har gjorts.

- vad (det) gäller _ - Träffar på vad gäller har sorterats ut i de fall vad har interrogativ betydelse (ex.: Vad gäller saken?), primärt genom sökning på frågetecken.

Träffar på vad det gäller utan nominalt komplement har sorterats ut manuellt. I dessa fall har verbet sin absoluta betydelse (ex.: vad det gäller är ...; man måste veta vad det gäller).

- när det gäller

- Träffar på när det gäller utan komplement har sorterats ut, primärt genom sökning på gäller + komma/ punkt/frågetecken/utropstecken/citattecken/tankstreck samt på bäst/sämst när det gäller och när det gäller som.

- när det kommer till - Träffar på metaforen när det kommer till kritan har sorterats ut manuellt, liksom de belägg där det är referentiellt subjekt samt de belägg där det är expletivt subjekt som företrädare för postponerad att-sats (ex. när det kommer till min kännedom att ...).

- i fråga om - Ingen manuell utsortering har gjorts.

- med avseende på $\quad$ - Ingen manuell utsortering har gjorts.

Som förklaras nedan har en del beräkningar måst baseras på resultatet av denna första utsortering, vilken endast avser utrensning av irrelevanta sökträffar. Andra beräkningar utgår ifrån att också belägg som uppträder i identisk form två eller flera gånger i samma text uteslutits (se vidare nedan). Rent praktiskt har denna utrensning startat med att beläggen i varje text först sorteras i alfabetisk ordning, så att dubbletter uppträder i direkt följd och därmed relativt lätt kan upptäckas.

\subsection{Beräkningar}

Den kvantitativa analysen som behandlas i avsnitt 3 bygger på beräkningar av

- de olika avseendemarkörernas relativa frekvens (antal förekomster per en miljon tokens)

- fördelningen mellan olika avseendemarkörer inom enskilda korpusar

- fördelningen mellan olika avseendemarkörers olika komplement inom enskilda korpusar

- fördelningen mellan olika avseendemarkörer på fraser i olika syntaktiska positioner inom enskilda korpusar. 
När det gäller de relativa frekvenserna beräknas de, som framgått ovan, endast på materialet från DN 1987 och senare. Det är dessa beräkningar som baseras på antalet belägg inklusive dubbletter. I framför allt de senare korpusarna förekommer ganska många dubbletter (eller tripletter etc.). Detta hänger samman med att samma text kan förekomma i flera redigeringsversioner. Eftersom antalet tokens i materialet som helhet också inbegriper dessa olika textversioner, måste frekvensberäkningen utföras på alla relevanta förekomster inklusive dubbletterna.

I de övriga beräkningarna, som handlar om fördelningar inom enskilda korpusar, spelar korpusens totala antal tokens ingen roll. Dessa beräkningar utgår därför ifrån antalet belägg exklusive dubbletter.

\subsection{Akribi}

Det material som hanteras i undersökningen består av över 72000 belägg inklusive dubbletter och över 69000 belägg exklusive dubbletter. Med ett så stort material är det omöjligt att inom rimlig tid uppnå hundraprocentig korrekthet i alla beräkningar. Och även om den grammatiska taggningen bara har gjorts på ett delmaterial måste man även där räkna med en viss felmarginal, dels därför att också detta material trots allt är ganska stort och taggningen delvis måste göras via söktekniska knep, dels därför att det är svårt att alltid vara helt konsekvent i bedömningen av enskilda belägg.

Detta innebär emellertid inte något egentligt problem i sammanhanget; resterande fel och inkonsekvenser i sortering och taggning bör påverka resultaten av beräkningarna rätt marginellt (ofta endast på promille-nivå).

\section{Resultat}

I detta avsnitt presenteras resultatet av de beräkningar som beskrivs ovan. I avsnitt 3.1 redogörs för utvecklingen i stort; vinnare och förlorare i ett ganska kort och ett lite längre perspektiv identifieras. Avsnitt 3.2 handlar om de olika avseendemarkörernas grammatiska egenskaper och vad som utmärker en vinnare. 


\subsection{Vinnare och förlorare}

\subsubsection{Det korta perspektivet}

Redan i det korta perspektiv som korpusarna från 1987 till 2013 representerar kan man se några tydliga tendenser. Det finns, som nämnts, två nykomlingar: gällande och när det kommer till. Som framgår av figur 2 ligger gällande ett litet steg före i processen; när det kommer till är belagt en enda gång i DN 87.

Samtidigt som gällande och när det kommer till är på väg upp finns det några avseendemarkörer som tydligt är på väg ner, främst beträffande, $i$ fråga om och vad (...) beträffar, se figur 3 .

Den verklighet som återspeglas i figurerna 2 och 3 visar emellertid bara ett mikroperspektiv. Om man tar alla avseendemarkörer i beaktande måste man konstatera att det är två varianter som är överlägset mycket vanligare än de övriga, nämligen när det gäller och vad (det) gäller. Som framgår av tabell 1 varierar den relativa frekvensen stort mellan olika avseendemarkörer. När det gäller är faktiskt vanligare än samtliga de övriga tillsammans. Det näst vanligaste uttrycket, vad (det) gäller, uppvisar en frekvens som är ungefär en fjärdedel av den för när det gäller, men samtidigt betydligt högre än övriga uttrycks frekvenser. Det står också klart att vissa avseendemarkörer är tämligen blygsamt belagda i materialet.

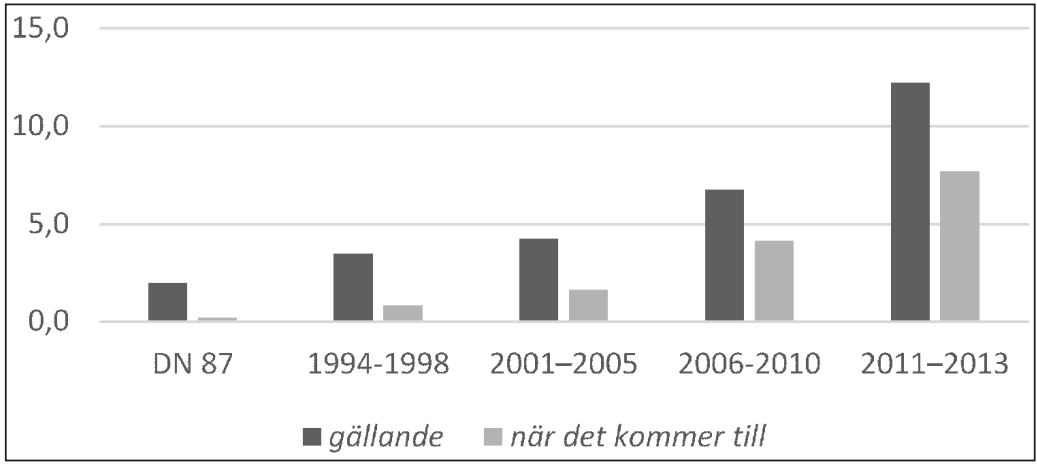

Figur 2. Den relativa frekvensen för gällande och när det kommer till 19872013. Antal belägg per en miljon tokens. 


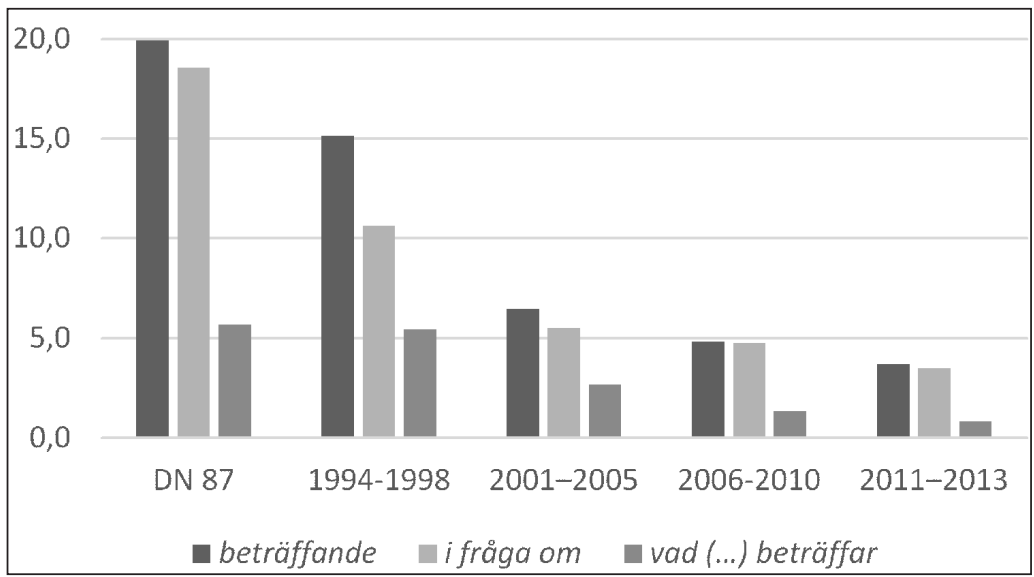

Figur 3. Den relativa frekvensen för beträffande, i fråga om och vad (...) beträffar 1987-2013. Antal belägg per en miljon tokens.

Tabell 1. Den relativa frekvensen för samtliga avseendemarkörer. Antal belägg per en miljon tokens.

\begin{tabular}{lrrrrr}
\hline & & $1994-$ & $2001-$ & $2006-$ & $2011-$ \\
& DN 87 & 1998 & 2005 & 2010 & 2013 \\
\hline angående & 8,4 & 10,9 & 10,9 & 10,8 & 14,1 \\
avseende & 0,6 & 3,0 & 3,2 & 3,0 & 3,1 \\
beträffande & 19,9 & 15,2 & 6,5 & 4,8 & 3,7 \\
gällande & 2,0 & 3,5 & 4,2 & 6,7 & 12,2 \\
rörande & 5,5 & 7,2 & 5,5 & 5,4 & 5,9 \\
vad (...) angår & 0,2 & 0,2 & $<0,1$ & 0,0 & 0,0 \\
vad avser & 1,2 & 1,0 & 0,6 & 0,4 & 0,6 \\
vad (...) beträffar & 5,7 & 5,4 & 2,7 & 1,3 & 0,8 \\
vad (det) gäller & 36,1 & 44,1 & 38,1 & 34,0 & 31,7 \\
när det gäller & 134,8 & 146,9 & 137,0 & 139,4 & 127,6 \\
när det kommer till & 0,2 & 0,8 & 1,6 & 4,1 & 7,7 \\
i fråga om & 18,6 & 10,6 & 5,5 & 4,8 & 3,5 \\
med avseende på & 0,4 & 1,1 & 1,2 & 0,9 & 0,6 \\
\hline
\end{tabular}

\subsubsection{Ett lite längre perspektiv}

Eftersom korpusarna före 1987 inte är tillräckligt stora för att beräkna relativa frekvenser som är jämförbara med de senare korpusarnas är tidsperspektivet i föregående avsnitt mycket kort. En viss uppfattning om utvecklingen på lite längre horisont kan man däremot få genom att jämföra de olika avseendemarkörernas andelar inom respektive korpus. Dessa presenteras i tabell 2 . 
Tabell 2. Den procentuella fördelningen mellan de olika avseendemarkörerna i de olika korpusmaterialen. I de fall en avseendemarkör är belagd men andelen understiger $1 \%$ markeras det med $<1$. En nolla innebär att belägg helt saknas.

\begin{tabular}{lrrrrrrrr}
\hline & $\begin{array}{c}\text { ORDAT } \\
(\%)\end{array}$ & $\begin{array}{r}\text { P 65 } \\
(\%)\end{array}$ & $\begin{array}{r}\text { P76 } \\
(\%)\end{array}$ & $\begin{array}{r}\text { DN 87 } \\
(\%)\end{array}$ & $\begin{array}{r}94-98 \\
(\%)\end{array}$ & $\begin{array}{c}01-05 \\
(\%)\end{array}$ & $\begin{array}{c}06-10 \\
(\%)\end{array}$ & $\begin{array}{c}11-13 \\
(\%)\end{array}$ \\
\hline angående & 6 & 4 & 5 & 4 & 4 & 5 & 5 & 7 \\
avseende & 2 & $<1$ & $<1$ & $<1$ & 1 & 1 & 1 & 1 \\
beträffande & 28 & 16 & 12 & 8 & 6 & 3 & 2 & 2 \\
gällande & $<1$ & 1 & 1 & $<1$ & 1 & 2 & 3 & 6 \\
rörande & 20 & 5 & 4 & 2 & 3 & 3 & 2 & 3 \\
vad (...) angår & 3 & 2 & $<1$ & $<1$ & $<1$ & $<1$ & 0 & 0 \\
vad avser & 0 & $<1$ & $<1$ & $<1$ & $<1$ & $<1$ & $<1$ & $<1$ \\
vad (...) beträffar & 12 & 9 & 5 & 2 & 2 & 1 & $<1$ & $<1$ \\
vad (det) gäller & $<1$ & 4 & 9 & 15 & 18 & 18 & 16 & 15 \\
när det gäller & 3 & 40 & 53 & 58 & 59 & 63 & 65 & 60 \\
när det kommer till & 0 & 0 & 0 & $<1$ & $<1$ & $<1$ & 2 & 4 \\
i fråga om & 22 & 19 & 9 & 8 & 4 & 3 & 2 & 2 \\
med avseende på & 3 & 1 & $<1$ & $<1$ & $<1$ & $<1$ & $<1$ & $<1$ \\
\hline
\end{tabular}

När man förlänger perspektivet på detta sätt får man en bild av det tidiga 1900-talet som kan förvåna. I ORDAT-korpusen är det inte alls när det gäller och vad (det) gäller som dominerar. Dessa uttryck är där tvärtom rätt ovanliga. I stället är det beträffande som är den vanligaste avseendemarkören med en andel av $28 \%$, tätt följd av i fråga om på $22 \%$ och rörande på $20 \%$. Samtliga dessa sjunker därefter gradvis till dagens låga andelar mellan 2 och $3 \%$. Uttrycket vad (...) beträffar, som nu i stort sett är helt försvunnet, är också förhållandevis vanligt i ORDAT med en andel på $12 \%$. När det gäller och vad (det) gäller gör den motsatta karriären, framför allt det förra uttrycket närmast exploderar under andra halvan av förra seklet och tycks ha landat någonstans runt $60 \%$.

Med tanke på att texterna i ORDAT-korpusen ger ett betydligt formellare intryck än texterna i de senare korpusarna kan man förstås fråga sig om utfallet för denna korpus snarast är en fråga om stil. De delvis dramatiska skillnaderna talar dock emot den hypotesen; stilskillnader kan spela in, men inom vissa gränser. För övrigt faller siffrorna för Press 65 och Press 76 väl in mellan dem för ORDAT och DN 87, vilket styrker den allmänna bild som tabell 2 antyder.

För en modern språkbrukare kan det emellertid förefalla anmärkningsvärt att de nu i särklass vanligaste avseendemarkörerna spelade en så blygsam roll för bara sjuttio år sedan. För att ytterligare undersöka rimligheten i detta har jag sökt efter när det gäller och hvad (det) gäller i några av Språkbankens tidnings- 
korpusar från 1800-talet, nämligen Aftonbladet från 1830-tal till 1860-tal. ${ }^{9}$ Sammantaget består de fyra korpusarna av ca 200 miljoner tokens, och totalt uppvisar dessa 290 belägg på avseendemarkören när det gäller, vilket innebär en relativ frekvens om 1,45 per miljon tokens. En så låg förekomst tyder på att när det gäller var en novation ungefär vid sekelskiftet 1800. Sökningen på hvad (det) gäller resulterade inte i några belägg alls, vilket talar för att denna avseendemarkör kanske uppstått runt nästa sekelskifte, dvs. omkring 1900.

\subsubsection{Vinnare och förlorare - en summering}

Genomgången ovan visar vinnare och förlorare bland avseendemarkörerna i ett kort och ett halvlångt perspektiv. Man kan se att gällande och när det kommer till går stadigt framåt i det korta perspektivet. Men dessa uttryck har ännu inte hunnit så långt i sin karriär.

I ett lite längre perspektiv kan man se att flera tidigare dominerande uttryck - beträffande, rörande, vad (...) beträffar och i fråga om - är på reträtt, delvis nästan borta. I gengäld har när det gäller och vad (det) gäller kommit på bred front.

Vissa uttryck, nämligen avseende, vad avser, vad (...) angår och med avseende $p a ̊$, har under hela den period som undersökningen täcker spelat en marginell roll. (Intressant nog gäller det alltså alla de uttryck som utgår ifrån verbet avse.) Dessa uttryck kan ha varit vanligare tidigare, men det behöver förstås inte vara så.

\subsection{Vad utmärker en vinnare?}

\subsubsection{Avseendemarkörernas komplement}

Avseendemarkörer kan i varierande omfattning ta som komplement vanliga nominalfraser, nominala bisatser och att-inledda infinitivfraser, se de respektive fetstilta leden i $(7 \mathrm{a}-\mathrm{c})$.

(7) a. Vad utlandsresandet angår, står man inför en revolution av de franska levnadsvanorna. (Press 65)

b. Det finns inga föreskrifter angående hur höga strålvärden de fär ha. (GP 2002)

c. Danskarna ligger långt före svenskarna när det kommer till att skriva manus. (GP 2005)

\footnotetext{
${ }^{9}$ Språkbankens presskorpusar från 1800-talet är maskininlästa men (i skrivande stund) inte vidare bearbetade. Detta innebär vissa problem som har förhindrat mig att generellt utsträcka denna undersökning till 1800-talet.
} 
I tabell 3 redovisas för de i modern svenska nio vanligaste avseendemarkörerna andelen nominalfraskomplement (NF), bisatskomplement (BS) och infinitivkomplement (IF) i materialets tre sista korpusar, dvs. GP 2011-2013. De uttryck som redovisas är i detta material representerade med ett antal belägg från 137 (avseende) till 5300 (när det gäller). De uttryck som inte redovisas uppvisar som mest endast 44 belägg i de tre korpusarna tillsammans. Beräkningarna för när det gäller avser här endast denna exakta fras, dvs. inbegriper inte de varianter som inleds med då eller som har verbet i preteritum. På motsvarande sätt avser beräkningarna för vad gäller inte varianter med expletivt det och/eller preteritum.

Tabell 3. Procentandelen nominalfras-, bisats- och infinitivfras-komplement i GP 2011-2013 för de nio vanligaste avseendemarkörerna.

\begin{tabular}{lccc}
\hline $\begin{array}{l}\text { Avseendemarkör } \\
(\mathrm{n})=\text { beräkningsunderlag }\end{array}$ & $\begin{array}{c}\text { NF } \\
(\%)\end{array}$ & $\begin{array}{c}\text { BS } \\
(\%)\end{array}$ & $\begin{array}{c}\text { IF } \\
(\%)\end{array}$ \\
\hline angående $(615)$ & 93 & 6,5 & 0,3 \\
avseende $(137)$ & 99 & 1,5 & 0,0 \\
beträffande $(180)$ & 97 & 2,8 & 0,0 \\
gällande (528) & 97 & 2,7 & 0,6 \\
rörande (255) & 98 & 2,0 & 0,0 \\
vad gäller $(1274)$ & 97 & 0,7 & 1,9 \\
när det gäller $(5$ 300) & 88 & 2,3 & 9,2 \\
när det kommer till (351) & 88 & 1,4 & 11,1 \\
i fråga om $(164)$ & 94 & 2,4 & 3,7 \\
\hline
\end{tabular}

Som framgår av tabell 3 är det ovanligt att särskilt de participformade avseendemarkörerna tar infinitivkomplement. Bland participen utmärker sig däremot angående genom en förhållandevis hög andel (6,5 \%) bisatskomplement. Generellt sett är bisatskomplement annars inte så vanliga. Ett bidrag till den möjligen förvånansvärt höga andelen angående med bisatskomplement kan vara en förkärlek för denna preposition när man refererar hur någon kommenterar ett förhållande, en händelse eller en diskussionspunkt som måste återges med en hel sats, se t.ex. (8a). Ibland förkommer angående även i icke-satsformade meningar som den i (8b), som man kan misstänka är en förklaring efter ett återgivet citat.

(8) a. »Nu gäller det att stå på egna ben», säger han angående att föreningen inte längre får EU-bidrag till sin verksamhet. (GP 2013)

b. Restaurang Sjömagasinets ägare angående att man återerövrat sin prestigefulla stjärna i Guide Michelin. (GP 2013) 
Det kanske intressantaste resultatet i tabell 3 är emellertid att både när det gäller och när det kommer till har en i sammanhanget hög andel infinitivkomplement, 9,2\% respektive $11,1 \%$. Går man hela vägen tillbaka till 1800-talsmaterialet visar det sig dessutom att andelen för när det gäller i själva verket har varit mycket högre. I 1800-talsmaterialet ligger den på 40 \% för att sedan sjunka successivt till dagens nivå, se figur 4 . Man kan därmed tänka sig att just benägenheten att ta infinitivkomplement kan ha varit en viktig egenskap för att bana väg för detta uttrycks inträde bland avseendemarkörerna. I figur 4 redovisas även utvecklingen för när det kommer till från perioden 1994-98 och framåt. Denna avseendemarkör ser inte ut att ha startat på samma sätt som när det gäller. Bara 2 av de 50 första beläggen t.o.m. 1998 (ett vardera i Press 96 och Press 97) har infinitivkomplement.

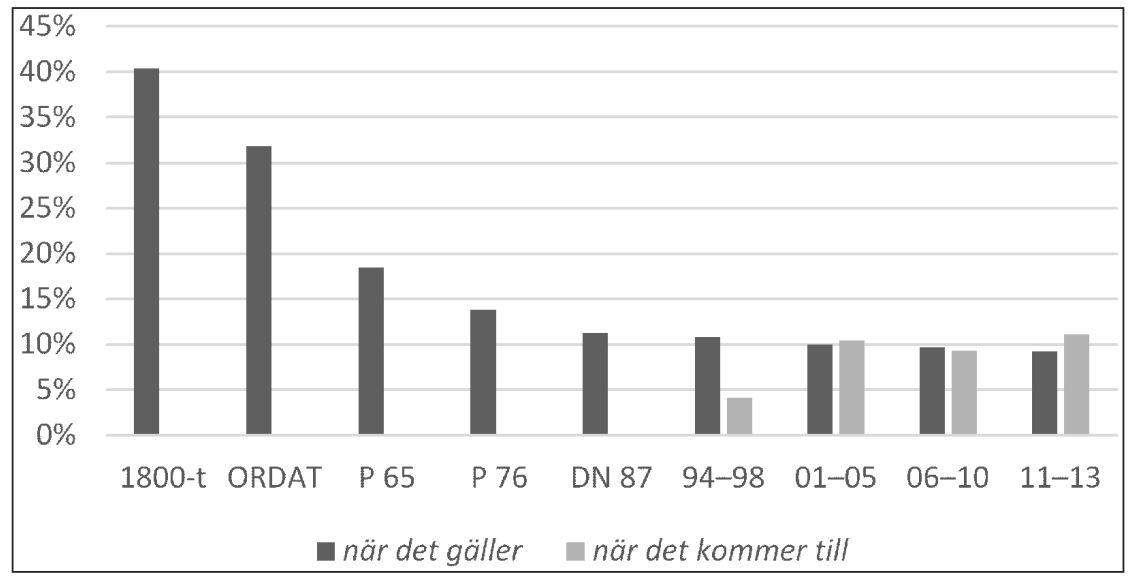

Figur 4. Andelen infinitivkomplement för när det gäller och när det kommer till i de olika korpussamlingarna.

Att både när det gäller och när det kommer till tycks ha landat på en nivå av ungefär $10 \%$ infinitivkomplement kan tyda på att det är en naturlig andel för en avseendemarkör som utan problem kan ta alla typer av komplement.

\subsubsection{Avseendefrasernas syntaktiska funktioner}

Som framhållits ovan kan de fraser som inleds av avseendemarkörer fungera både som attribut och adverbial. Det är emellertid inte alltid så enkelt att avgöra när man ska räkna med det ena eller det andra. I (9a) återges ett belägg från materialet, där frasen i fråga om tolerans är tvetydig i detta avseende. Man kan 
t.ex. spela med ledföljden och placera den nämnda frasen ensam i fundamentet som i (9b); i så fall skulle den klassas som adverbial. Men det går lika bra att som i (9c) sätta den längre sekvensen några föredömen i fråga om tolerans $\mathrm{i}$ fundamentet; i det fallet skulle avseendefrasen betraktas som ett attribut till föredömen.

(9) a. Dessa immigranter var dock knappast [...] några föredömen i fråga om tolerans. (Press 65)

b. I fråga om tolerans var dessa immigranter dock knappast några föredömen.

c. Några föredömen $i$ fråga om tolerans var dessa immigranter dock knappast.

Den mycket stora andelen tvetydiga belägg gör det mer eller mindre omöjligt att med hjälp av en regelrätt syntaktisk analys utröna hur olika avseendefraser fördelar sig på olika funktioner. Samtidigt är det förstås intressant att få någon uppfattning om hur fraserna förhåller sig till varandra härvidlag, utifrån hypotesen att en vinnande avseendemarkör bör ha en allsidig användning. För detta ändamål har därför en förenklad analys gjorts, som i stort utgår ifrån en mekanisk sortering av avseendefrasernas placering i satsen.

För att få ett övergripande mått på avseendefrasers tendens att fungera attributivt har sådana avseendefraser som står efter substantiv (exklusive egennamn) och i direkt anslutning till dessa kategoriserats som »Post-N». Undantag har dock gjorts för fraser efter substantiv som ingår i vissa konventionaliserade uttryck, t.ex. ligga i framkant(en)/täten/toppen/botten, lägga åt sidan, se genom fingrarna, sätta ner foten, byta fot, spela en (...) roll, ord står mot ord, till exempel, $i$ alla fall. Avseendefraserna är i dessa fall knappast attribut till det föregående substantivet och undantas eftersom de inte så sällan ansluter just till uttryck av den nämnda typen. I övrigt är sorteringen helt mekanisk. Långt ifrån alla fraser som klassats som post-N är attribut, vilket i någon mån uppvägs av att det å andra sidan också finns attributiva fraser som inte fångas genom metoden. Men osäkerheten är hög, och poängen är helt enkelt endast att stora skillnader i andelen Post-N-fraser inledda med olika avseendemarkörer trots allt bör avspegla skillnader i deras benägenhet att fungera attributivt.

Vid sidan om kategoriseringen som Post-N noteras för de olika avseendefraserna hur stor andel som är adverbial i fundamentspositionen, som i (10a), samt hur stor andel som används som fria topikfraser, dvs. dislokerade till vänster om fundamentet, som i (10b). Förekomst i dessa positioner säger naturligtvis en del om vilka av uttrycken som gärna används som »topikmarkörer», men samtidigt är det ett tecken på frasernas adverbiella karaktär. Fraser som inte fal- 
ler inom någon av de tre nämnda kategorierna klassas som »övriga»; dessa kan vara såväl adverbiella som attributiva.

(10) a. När det gäller bostadsrätter är det föreningen som bestämmer. (GP 2013)

b. Angående fransmännen; vem har sagt att de är så kloka? (GP 2002)

I tabell 4 redovisas hur fraser som inleds med de i dagens svenska nio vanligaste avseendemarkörerna fördelas på de olika syntaktiska positionerna i GP 2011-13. Som i föregående avsnitt har de mindre vanliga varianterna till vad gäller och när det gäller utelämnats ur undersökningen.

Tabell 4. Procentuell fördelning på syntaktiska positioner i GP 2011-13 för fraser inledda med de nio vanligaste avseendemarkörerna. Post-N = ställning i direkt anslutning till ett substantiv, $\mathrm{Fu}=$ fundamentsplacerat adverbial, Fri topik $=$ vänsterdislokerat fritt topikled.

\begin{tabular}{lcccc}
\hline $\begin{array}{l}\text { Inledande avseendemarkör }(\mathrm{n})= \\
\text { beräkningsunderlag }\end{array}$ & $\begin{array}{c}\text { Post-N } \\
(\%)\end{array}$ & $\begin{array}{c}\text { Fu } \\
(\%)\end{array}$ & $\begin{array}{c}\text { Fri topik } \\
(\%)\end{array}$ & $\begin{array}{c}\text { Övriga } \\
(\%)\end{array}$ \\
\hline angående $(615)$ & 52 & 7 & 8 & 33 \\
avseende $(137)$ & 73 & 2 & 0 & 25 \\
beträffande $(180)$ & 39 & 28 & 4 & 28 \\
gällande $(528)$ & 68 & 5 & 1 & 26 \\
rörande $(255)$ & 79 & 1 & 0 & 20 \\
vad gäller $(1274)$ & 36 & 20 & 0 & 44 \\
när det gäller (5 300) & 31 & 30 & 0 & 39 \\
när det kommer till (351) & 30 & 27 & 0 & 43 \\
i fråga om $(164)$ & 35 & 11 & 0 & 54 \\
\hline
\end{tabular}

Som framgår av tabellen står fraser som inleds med de participformade avseendemarkörerna oftare i Post-N-positionen än övriga uttryck, vilket är logiskt om man utgår ifrån att de har sitt ursprung i efterställda attributiva particip och fortsatt prioriterar den attributiva funktionen. Fraser som inleds med beträffande avviker dock från de övriga genom en mera varierad fördelning. Uppenbarligen används dessa gärna även som adverbial. Detta kan ha underlättats av att verbet beträffa egentligen endast överlevt i uttrycken beträffande och vad (...) beträffar, vilka därigenom möjligen fått »leva sitt eget liv». De är dock svårt att visa om så verkligen är fallet. Oavsett orsaken till beträffande-frasernas varierade användning, så ligger det nära till hands att se den som en förutsättning för den dominerande ställning bland avseendemarkörerna som beträffande tidigare haft.

Några av participuttrycken utmärker sig också genom att förekomma i fria topikfraser, vilket andra typer av avseendemarkörer sällan gör. (Belägg på 
detta saknas helt i materialet från 2011-13.) Inte minst gäller det angående som fått en särskild roll i ärenderubriceringar; i pressmaterialet dyker uttrycket upp t.ex. som rubrik till insändare. Förklaringen påminner en del om den som ovan getts till fenomenet att samma preposition jämförelsevis ofta tar bisatskomplement.

I övrigt är det beträffande och, i någon mån, gällande som förekommer i fria topikled. Med tanke på att prepositionen gällande är relativt ny kan man tänka sig att den är stadd i utveckling och att gällande-fraser rör sig mot en syntaktisk fördelning som liknar den beträffande-inledda fraser har idag (och som de mer eller mindre tycks ha haft under hela undersökningsperioden).

Fraser som inleds med de fyra icke-participformade avseendemarkörerna uppträder både som attribut och som adverbial. Intressant nog gäller detta även fraser som inleds med den tämligen nya avseendemarkören när det kommer till, för vilka det är lätt att tänka sig en rent adverbiell start och där man därför kanske hade förväntat sig en lägre andel post-N. En närmare titt på när det kommer till-fraser i post-N-position i hela materialet visar emellertid att andelen stadigt ökar från 12 \% i korpusarna från 1994-98 till de 30 \% som redovisas för 201113 i tabell 4. Det tyder på en utomordentligt stark och snabb etablering av uttrycket som avseendemarkör.

Siffrorna för tiden före 2011-13 bekräftar också att när det kommer till-fraser verkligen startat som adverbial, dessutom som adverbial i fundamentet.

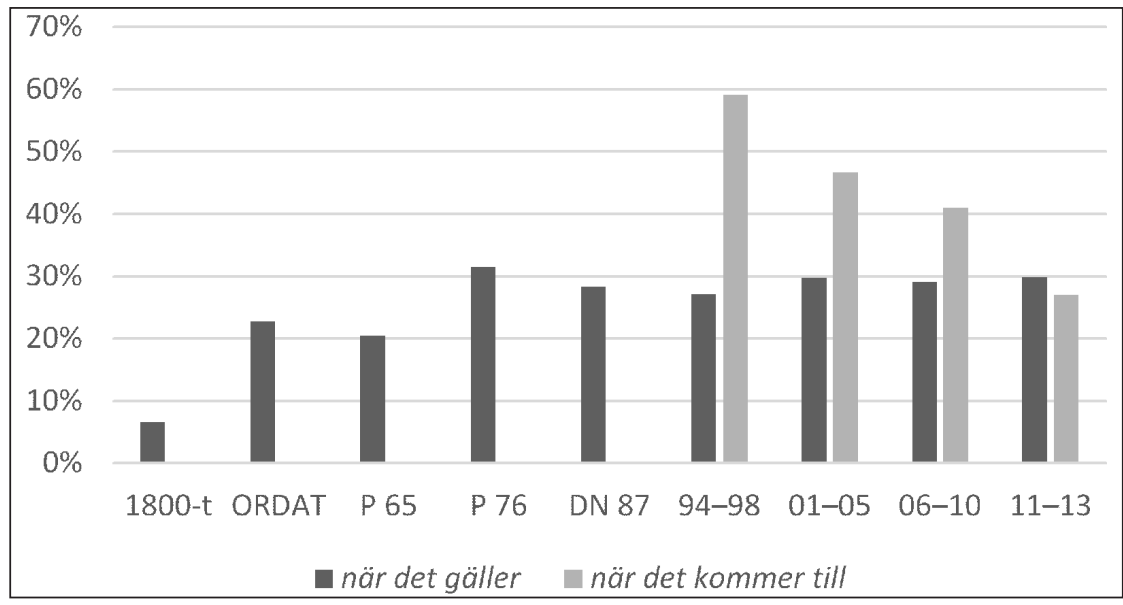

Figur 5. Andelen fundamentsplacerade adverbial för fraser som inleds med när det gäller och när det kommer till i de olika korpussamlingarna. 
Man kan i detta avseende jämföra utvecklingen med fraser inledda med när det gäller, se figur 5 där andelen fundamentsplacerade adverbial för fraser inledda med när det gäller respektive när det kommer till redovisas. Här framgår att när det gäller-fraserna inledningsvis inte så ofta förekom som fundament, medan när det kommer till-fraserna företrädesvis hade just denna position när de först dök upp. Skärskådar man beläggen ytterligare visar det sig att det enda belägget i DN 87 och samtliga nio i GP 1994 var av detta slag.

Som framgår av figur 5 tycks när det gäller-fraserna ha landat på en andel mellan 25 och $30 \%$ adverbialsfundament. Samma andel gäller för när det kommer till-fraserna i de senaste av de undersökta korpusarna - och även för beträffande-fraser (jfr tabell 4). Det finns därmed kanske anledning att tro att denna nivå är den naturliga för en avseendemarkör som lika gärna inleder attributiva som adverbiella fraser och att den nedåtgående trenden för när det kommer till nu kommer att plana ut.

\subsubsection{Vad utmärker en vinnare? - en summering}

Den dominerande avseendemarkören i modern svenska, när det gäller, utmärker sig dels genom att gärna ta infinitivfraser som komplement, dels genom att fraser inledda med detta uttryck fungerar väl i olika syntaktiska positioner och också relativt ofta används som topikaliserat adverbial. Infinitivkomplement förekommer numera utan problem även med när det kommer till, men är i övrigt ovanliga, i synnerhet efter de participformade avseendemarkörerna. Det senare uttrycket liknar det förra även genom en liknande spridning på syntaktiska positioner.

De båda nämnda uttrycken är alltså formellt ganska lika, men tycks ha startat på olika sätt: när det gäller kan en gång ha tagit sig in på arenan just genom att ta infinitivkomplement, medan när det kommer till ursprungligen $\mathrm{i}$ huvudsak förekom i topikfraser. Man får av figurerna 4 och 5 intrycket att när det gäller landat i andelar som står i direkt proportion till uttrycksbehoven beträffande infinitivkomplement och som inledare av topikfraser under senare delen av 1900-talet, medan när det kommer till raskt närmat sig samma nivåer under den korta tid uttrycket varit aktuellt som avseendemarkör i svenskan.

Bland de participformade prepositionerna utmärker sig den tidigare så dominerande beträffande som mindre bunden till attributiva fraser än de övriga. Dess andel som inledare av topikaliserade adverbial är i paritet med andelen för när det gäller och när det kommer till. 
En egenskap som talar till de participiella uttryckens fördel är att de, åtminstone ett par av dem, lättare än de övriga avseendemarkörerna tycks fungera bra som inledare av fria topikfraser. I första hand beträffande och - i särskilt hög grad - angående används så. Även gällande förekommer i dessa fraser, men (så långt materialet sträcker sig) i mera begränsad omfattning.

\section{Slutsatser och kommentarer}

\subsection{Ett dynamiskt fält med många spelare}

Resultaten av undersökningen visar tydligt att avseendemarkörer kommer och går. Det gör de till och med i så hög grad att det inte är oproblematiskt att studera fältet »markera avseende» utan att anlägga ett diakront perspektiv. Mina siffror för angående, beträffande, gällande och rörande för perioden 1994-98 visar ungefär samma inbördes fördelning som Granvik \& Taimitarha (2014) fann för samma ord i PAROLE-korpusen, även om beträffande i mitt material inte är fullt så dominerande som i PAROLE och angående något vanligare än rörande (i PAROLE är de ungefär lika vanliga); gällande svarar för en relativt blygsam andel i båda materialen. Men ett decennium senare ser det helt annorlunda ut. Redan i början av 00-talet har beträffande tappat stort. Och perioden 2011-13 visar det omvända styrkeförhållandet mellan beträffande och gällande jämfört med 1994-98.

Samtidigt består vissa skillnader mellan orden. Granvik \& Taimitarha (2014 s. 284) finner att angående i högre grad än övriga används vid ord för kommunikation, vilket rimmar väl med min iakttagelse att denna prepositions höga andel bisatskomplement kan hänga samman med att den gärna används när någon kommenterar en omständighet som refereras med en hel bisats (jfr avsnitt 3.2.1 och exempel (8a)). Sådana subtila drag hos enskilda uttryck kan innebära att de intar en egen liten nisch i systemet och kvarstår utan att i så hög grad breda ut sig på andras bekostnad.

Granvik \& Taimitarha (2014 s. 283 f.) konstaterar också att gällande används ungefär som beträffande, fastän mycket mer sällan - och företrädesvis som attribut, medan beträffande är vanligt även i adverbiell ställning. Ett skäl till den låga andelen gällande skulle kunna vara, resonerar författarna, att detta ord (olikt beträffande) inte bara är en preposition, utan också används som adjektiv och verbalt particip. Den senare utvecklingen visar emellertid att den förklaringen knappast håller; numera föredras gällande i många fall. 
Intressant nog visar emellertid beträffande fortsatt en större benägenhet än gällande att inleda adverbial, gärna i fundamentet. Detta behöver nu inte vara bestående, men det aktualiserar en annan sida av avseendemarkörernas utbytbarhet. Det stora fallet för beträffande startade sannolikt i mitten av det förra seklet; andelen i 90-talstexterna är bara en bråkdel av den man finner i ORDAT-korpusen med texter från förra halvan av 1900-talet. Men detta fall beror inte på att beträffande ersatts med en annan participformad preposition, utan på att (främst) när det gäller, som ofta inleder adverbiella fraser och gärna står i satsinitial position, kommit på bred front. I ORDAT-korpusen svarar beträffande tillsammans med rörande, i fråga om och vad (...) beträffar för $82 \%$ av alla belägg på avseendefraser, medan när det gäller tillsammans med vad (det) gäller används i 75 \% av fallen i GP 2011-13 (jfr tabell 2).

En så dramatisk ommöblering bland spelarna på fältet »markera avseende» hade knappast varit möjlig om uttrycken inte kunde tillmätas en mycket stor semantisk och funktionell överlappning. Deras formella uppbyggnad - om det rör sig om ett före detta particip, en finit bisatsinledning eller en komplex preposition (enligt mönstret preposition + substantiv + preposition) - tycks inte vara ett hinder för att utveckla en bred användningspotential. I många fall kan uttryck av olika form utan vidare ersätta varandra.

\subsection{Hur uppstår och utvecklas en avseendemarkör?}

Det framhölls inledningsvis att grammatikalisering spelade en stor roll vid uppkomsten av olika avseendemarkörer. Men grammatikalisering är inte den enda möjliga förklaringen.

För komplexa prepositioner som bygger på mönstret preposition + substantiv + preposition kanske man helt enkelt kan nöja sig med att tala om uttrycken som lexikaliserade. I SAG (del 2 s. 716, 718 f.) används termen lexikalisering även om avseendemarkörer av de andra typerna, vilket väl kan försvaras om man endast ser på lexikalisering som uppkomsten av nya lexikonenheter (jfr Svanlund 2002 s. 41), men jag ser en viss skillnad i hur detta gått till. Uttryck som $i$ fråga om och med avseende på kan ses som produktivt bildade fraser som stelnat och egentligen inte så mycket mer, till skillnad från exempelvis rörande och gällande, för vilka man måste räkna med en omtolkning från verbalt particip till preposition (dvs. en grammatikalisering).

En annan möjlighet är att helt enkelt importera avseendemarkörer eller åtminstone bilda dem på utländsk förebild. Det tyska inflytandet gör sig gällande i både angående och beträffande och motsvarande finita uttryck vad (...) angår 
och vad (...) beträffar. Att komplementet i de senare uttrycken kan stå före verbet kan också hänga samman med det tyska ursprunget, men skulle också kunna förklaras som en så kallad kilkonstruktion.

Ett intressant drag beträffande de finita vad-inledda uttrycken är att man egentligen rent formellt skulle förvänta sig en preposition före $v a d$, företrädesvis $i$. - Utan preposition är dessa uttryck, strukturellt sett, så kallade fria relativsatser. En preposition skulle göra dem till prepositionsfraser, vilket skulle stå i bättre samklang med hur de används. - Men det är mycket ovanligt att vad föregås av en preposition och förekommer i mitt material aldrig vid verben angå och beträffa. Däremot finns det nio belägg på motsvarande uttryck med gälla, t.ex. det i (11a), och ett belägg på $i$ vad avser, i ett pastischartat citat ur Grönköpings Veckoblad, se (11b).

(11) a. Stora teatern hade återigen försprång $i$ vad det gäller aktualiteter: [...] (ORDAT: 1930)

b. [...] och finnes för dagen egentl. föga övrigt att tillönska sig, åtm. $i \mathrm{vad}$ avser en lika färgrik som vidsträckt flora [...] (Press 98)

Den regelmässiga avsaknaden av preposition i de finita avseendemarkörerna som inleds med vad talar för att mönstret som sådant är fast förankrat i vår språkliga repertoar. Möjligen är det importerat från början, men det fungerar även i senare novationer som vad avser och vad (det) gäller.

En avseendemarkör där man med stor säkerhet kan se en direkt utländsk förebild är förstås när det kommer till, som utan tvivel måste antas vara en direkt överföring från engelskans when it comes to. Det spännande med detta uttryck är att det tycks ha tagit sig in i svenskan som renodlad topikmarkör, men anpassat sig oerhört snabbt och nu uppvisar samma distribution som när det gäller både vad avser komplementtyper och vilka syntaktiska positioner de fraser de inleder kan inta.

Andra avseendemarkörer förefaller emellertid ha utvecklats på rent svensk botten. Av dessa tar SAOB upp endast rörande; deras förstabelägg på detta ord som preposition är från 1759. Verbet avse i den allmänna betydelse som går igen i vad avser och prepositionen avseende, tycks, enligt SAOB, ha en märklig etymologi och antas ha bildats sekundärt (och ganska sent) till substantivet $a v$ seende. (I en anmärkning framhålls särskilt om verbet avse i dess moderna betydelser att de »hafva ingen motsvarighet i danskan och kunna på det hela ej omedelbart återföras till tyska förebilder».) Det förefaller sannolikt att de participformade prepositionerna rörande och avseende genomgått grammatikaliseringsprocesser som liknar den för gällande, och vad avser ansluter, som sagt, till mönstret för vad angår och vad beträffar. 
Särskilt intressanta är de avseendemarkörer som utgår ifrån verbet gälla, dvs. när det gäller, vad (det) gäller och gällande. Som nämnts tas ingen av dessa upp i artikeln gälla från 1929 i SAOB. Och undersökningen bekräftar att de alla är ovanliga i svenskan under förra halvan av 1900-talet. Som framgått av avsnitt 3.1.2 är när det gäller belagt redan på 1800-talet, men uttrycket svarar endast för $3 \%$ av avseendemarkörerna i ORDAT-korpusen. Redan i Press 65 är andelen uppe i $40 \%$, så man kan verkligen tala om en kometkarriär. Som även nämnts är hvad (det) gäller inte belagt i de 1800-talskorpusar jag undersökt och kommer senare och långsammare än när det gäller. Med all sannolikhet är alltså vad (det) gäller sekundärt i förhållande till när det gäller.

Vad är det då som gör att när det gäller utvecklas till avseendemarkör? Man kan ju notera att uttrycket har en avvikande form jämfört med tidigare finita uttryck som blivit avseendemarkörer; det inleds med när, inte $v a d$, och dessutom följs den temporala inledaren av ett expletivt det. En annan omständighet som är intressant $\mathrm{i}$ sammanhanget är att andelen infinitivkomplement är anmärkningsvärt hög i det äldsta materialet.

Artikeln gälla (v. 4) i SAOB tar upp 6 huvudbetydelser, varav tre kan anses fullt levande. Den utslätade betydelse som verbet har i avseendemarkören när det gäller tas upp som 5: "vara fråga om, röra sig om, avse, [...] angå, (be)röra». Denna betydelse föregås av den betydlig äldre 'vara giltig', som behandlas under punkt 2, och bruket av gälla i uttryck som avser att något står på spel etc., som behandlas under punkt 4.

Som moment a) under punkt 5 behandlas den opersonliga konstruktionen. Här påpekas att den särskilt används med åtföljande infinitiv eller verbalabstrakt och att uttrycket »i dessa fall icke alltid [är] klart skilt från $4 d »$. Moment 4d) förtecknar fall där det gäller betyder 'det är nödvändigt' eller 'det är viktigt', och då ofta åtföljs av en infinitiv eller att-sats. Äldsta anförda belägg är hämtat från Dalins Argus (1734): »Då gäller det at försöka.» Man kan alltså tänka sig att verbet i den opersonliga konstruktionen det gäller med infinitiv från början haft en mer pregnant betydelse, men att kontexten ofta tillåtit en tolkning där den aktion som infinitiven betecknar inte framstår som särskilt viktig, utan bara vad det handlar om. Särskilt nära till hands är den tolkningen vid ett bisatsinledande när/då det gäller/gällde, vilket talar för att avseendemarkören uppkommit just så. Detta skulle även förklara dess starka benägenhet att konstrueras med infinitiver.

Verbet i när det gäller-fraser har numera i allmänhet en utslätad avseende-betydelse. Den mer specifika betydelsen att något står på spel eller liknande finns dock kvar i de fall komplement saknas, som t.ex. i som bäst när det 
verkligen gäller eller när det gäller som mest (fall som alltså inte ingår i undersökningen, se avsnitt 2.2).

Eftersom när det gäller-konstruktioner rent formellt ser ut som vilka temporala bisatser som helst kan man förstås fråga sig om vi egentligen i det här fallet har att göra med något mer än en sorts konventionalisering av den inledande kollokationen. Men då är det viktigt att notera att avseendemarkören när det gäller också kan inleda attribut, inte bara adverbiella led. En sådan funktionell expansion förutsätter en grammatisk omtolkning av uttrycket. Allt tyder också på att den utvidgningen $\mathrm{i}$ användningen ägt rum på ett tidigt stadium; i meningen i (12), från en av Aftonbladet-korpusarna, är det t.ex. svårt att uppfatta när det gäller-frasen som något annat än ett attribut till det föregående substantivet.

(12) Vi anföra här i förbigående ett kostligt exempel på Allehandas otroliga förplumpningsförmåga när det gäller att motsäga sig sjelf. (Aftonbladet, 1840-tal)

Hur ska vi nu, slutligen, se på betydelsen av när det gäller för uppkomsten av uttrycket vad (det) gäller, och senare dessa båda för uppkomsten av prepositionen gällande? Hade de senare uttrycken kunnat uppstå av sig själva? Ja, är nog svaret på den frågan, fast med det tillägget att vad (det) gäller-varianten säkert har anslutit sig till det etablerade mönster som redan förelåg i vad angår och vad beträffar; i övrigt är sannolikt den allmänna betydelsen 'angå, avse, röra' hos ett verb (som här gälla) tillräcklig för att olika avseendemarkörer ska kunna uppstå. Men det hindrar ju inte att ett uttryck ändå kan bana vägen för ett annat som bygger på samma verb.

\subsection{Vem vinner, vem förlorar?}

Resultaten av undersökningen styrker hypotesen att allsidig användbarhet är en konkurrensfördel för en avseendemarkör. Den nu utan jämförelse mest populära varianten, när det gäller, inleder både adverbiella och attributiva fraser, och gärna topikaliserade adverbial. Den kan även ta olika typer av komplement och utmärker sig särskilt genom en hög andel infinitivkomplement. I en ställning tycks dock participformade avseendemarkörer föredras framför när det gäller (och andra icke-participformade uttryck), nämligen som inledare av vänsterdislokerade fria topikfraser.

Av de participformade prepositionerna är beträffande den variant som förefaller mest allsidig. Som andra participbaserade avseendemarkörer tar den 
ogärna infinitivkomplement, men den inleder både attributiva och adverbiella fraser och den förekommer, till skillnad från när det gäller, även i fria topikfraser. Denna allsidighet bör ses i ljuset av ordets tidigare dominans; i ORDAT-korpusen är beträffande den vanligaste avseendemarkören av alla.

Samtidigt är allsidigheten uppenbarligen inte det enda som avgör utsikterna för en avseendemarkör. Det är ju bland annat påfallande att just det allsidiga beträffande nu tycks vara på väg ut ur svenskan. Tittar man lite bakåt visar det sig också att t.ex. rörande, som inte alls är en särskild allsidig avseendemarkör utan i hög grad håller sig till attributiva fraser, också var ganska vanlig under det tidiga 1900-talet. Det enskilda ordets egenskaper är alltså inte helt utslagsgivande; man måste också se till vilka medspelare det har. Utan när det gäller, och för all del vad (det) gäller, på banan tycks flera uttryck ha haft chansen.

Man kan ändå fråga sig varför beträffande i snabb takt tappar mark, liksom vad (...) beträffar. Kanske är »felet» bara att verbet beträffa i övrigt inte har någon plats i den moderna svenskan och att dessa uttryck därmed framstår som mer formella och utdaterade än de övriga, att de stilistiskt är på väg till samma avdelning som prepositionen anbelangande(s) eller subjunktionerna änskönt och alldenstund. Men också ett lexikalt okomplicerat och rimligt allsidigt uttryck som i fråga om, tidigare rätt vanligt, minskar också i snabb takt. Det är inte uppenbart varför.

Trots att avseendemarkörernas 1900-talshistoria till stor del tycks ha handlat om att i första hand när det gäller och i andra hand vad (det) gäller lagt beslag på en stor del av fältet »markera avseende», så ser man ändå just nu två uttryck som vinner mark, låt vara ännu på en låg nivå: gällande och när det kommer till. Hur kommer det att gå för dem?

Prepositionen gällande startade först och leder kvantitativt. Ännu i det senaste materialet ser den ut att uppträda företrädesvis i attributiva fraser, men den är långt ifrån begränsad till sådana. Mitt inledande exempel (1) visar ju gällande i en topikaliserad adverbiell fras, och den förekommer även i fria topikfraser. På så sätt ligger vägen öppen för gällande att bli det nya beträffande.

Anglicismen när det kommer till intar fortfarande en kvantitativt underordnad position. Men dess formella utveckling är imponerande snabb. Från att synbarligen ha startat som en ren topikmarkör används när det kommer till nu ungefär på samma sätt (om än inte i samma omfattning) som när det gäller, och båda uttrycken visar samma höga andel infinitivkomplement. Mycket talar alltså för att när det kommer till kan bli en allvarlig konkurrent till när det gäller. 


\section{Material}

Språkbanken: https://spraakbanken.gu.se/

\section{Litteratur}

Allén, Sture, 1970: Nusvensk frekvensordbok baserad på tidningstext. Del 1. Graford. Homografkomponenter. Stockholm: Almqvist \& Wiksell international (distr.).

Baayen, R. Harald, 2001: Word Frequency Distributions. Dordrecht: Kluwer Academic Publishers.

Granvik, Anton \& Taimitarha, Susanna, 2014: Topic-marking prepositions in Swedish. A corpus-based analysis of adpositional synonymy. I: Nordic Journal of Linguistics 37(2). S. 257-296.

Holm, Lisa, 1991: Satsadverbial eller sättsadverbial. I: M. Thelander (red.): Svenskans beskrivning 18: Förhandlingar vid Artonde sammankomsten för svenskans beskrivning, Uppsala den 25-26 oktober 1990. Lund: Lund University Press. S. 172-180.

Hopper, Paul \& Traugott, Elizabeth Closs, 2003: Grammaticalization. $2^{\text {nd }}$ ed. Cambridge: Cambridge University Press.

König, Ekkehard \& Kortmann, Bernd, 1991: On the reanalysis of verbs as prepositions. I: G. Rauh (red.): Approaches to Prepositions. (Tübinger Beiträge zur Linguistik 358.) Tübingen: Gunter Narr Verlag. S. 109-125.

Pocheville, Arnaud, 2015: The ecological niche: History and recent controversies. I: T. Heams, P. Huneman, G. Lecointre \& M. Silberstein (red.): Handbook of evolutionary thinking in sciences. Dordrecht: Springer. S. 547-586.

Rosenkvist, Henrik, 2006: Fyra vyer av begreppet grammatikalisering. I: V. Molnár, G. Paulsson \& G. Andersson (red.): Vetenskapssocieteten i Lund: Årsbok. S. 57-73.

SAG = Teleman, Ulf, Hellberg, Staffan \& Andersson, Erik, 1999: Svenska Akademiens grammatik. Stockholm: Norstedts Ordbok.

SAOB = Ordbok över svenska språket utgiven av Svenska Akademien. 1.-. 1893-. Lund.

SAOL = Ordlista över svenska språket utgiven av Svenska Akademien. 14 uppl., 2015. Stockholm: Norstedts.

Svanlund, Jan, 2002: Lexikalisering. I: Språk och stil NF 12. S. 7-45.

Svensk ordbok, 2009. Utgiven av Svenska Akademien. Stockholm: Norstedts. 